\title{
PHYTOSOCIOGICAL RESEARCH ON WET MEADOWS DOMINATED BY SCIRPUS SYLVATICUS L. IN CĂLIMANI AND GURGHIULUI MOUNTAINS (MUREȘ COUNTY)
}

\author{
Silvia OROIAN ${ }^{1}$, Mihaela SĂMĂRGHIŢAN ${ }^{2 *}$ \\ ${ }^{1}$ Department F1, Discipline of Pharmaceutical Botany, George Emil Palade University of Medicine, \\ Pharmacy, Science, and Technology of Târgu Mureș, Romania \\ ${ }^{2}$ Mureş County Museum, Department of Natural Sciences, 24 Horea Street, RO-540036 Târgu Mureş, \\ Romania
}

\author{
*Correspondence: \\ Mihaela SĂMĂRGHIȚAN \\ msamarghitan@yahoo.com
}

Received: 13 December 2019; Accepted: 23 December 2019; Published: 30 December 2019

\begin{abstract}
Phytosociological structure of the communities dominated by Scirpus sylvaticus was studied in the mountain area of Mureş County with focus on vegetation community organization, floristic composition and habitat conservation. The vegetation sampling and data analysis were done following standard procedures. The study of wet meadows from the Călimani and Gurghiului Mountains carried out in field during 20152019, highlights the presence of hygrophilous coenoses belonging to the Scirpetum sylvatici Ralski 1931 plant association. These wet meadows grow on alluvial, gleyic and acidophilous soils. The identified communities belong to Natura 2000 habitat 6430 Hydrophilous tall-herb fringe communities of plains in the montane to alpine levels. The conservation status of the habitat is good and very good and the floristic composition emphasizes a rich floristic diversity.
\end{abstract}

Keywords: plant association, habitat, conservation status, Mureş County.

\section{Introduction}

Phytosociological analysis indicates the organization and structure of the vegetation in a particular habitat which determines the distribution pattern of individuals from other species, and it is important for understanding the functioning of any community.

The diversity of semi-natural communities along the rivers beds and valley streams is determined by the variety of the habitat conditions both in terms of water content and soil fertility.

The study area is represented by the valleys of the following rivers: Mureș, Gurghiu, Niraj, Sebeș and Sovata. These are mountainous valleys stretching along the Gurghiului and Călimani Mountains in Mureș County. On the river side, plots with tall herbs and wet meadows occur. They belong to the Natura 2000 habitat 6430 Hydrophilous tallherb fringe communities of plains in the montane to alpine levels.

In the present investigation an attempt has been made to document the structure of plant communities, composition and diversity of some meadows from Gurghiului and Călimani Mountains. A phytosociological survey of the wet meadows dominated by Scirpus sylvaticus in the study area was made during 2015-2019. 


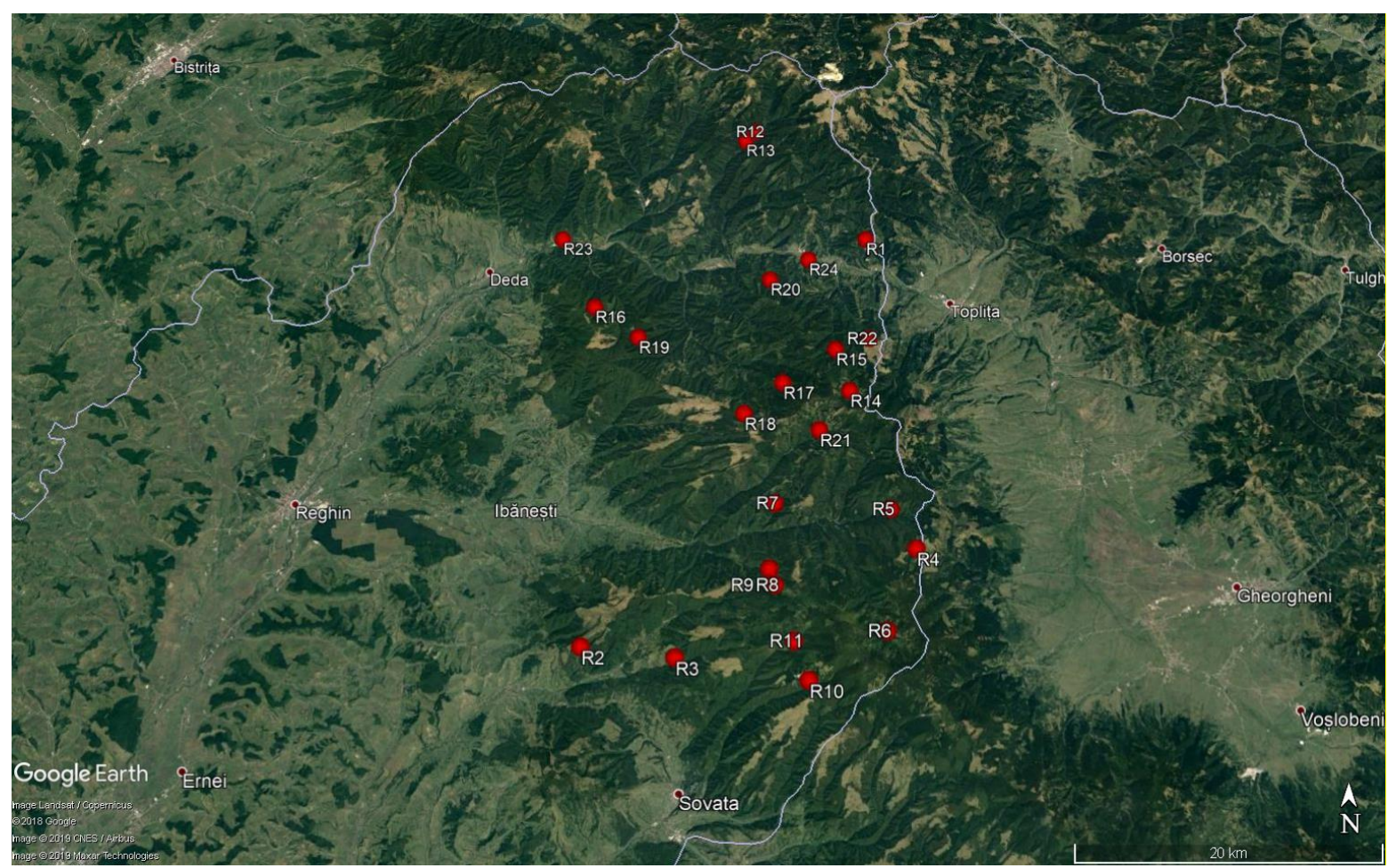

Fig. 1. The map with the location of relevées from Gurghiului and Călimani Mountains (Romania)

They were classified in the association Scirpetum sylvatici Ralski 1931. This association is wide spread in the East Carpathians; it was described from Bistriţa Aurie Valley by Pascal and Mititelu (1971) and Gergely and Raţiu (1973) within the Ciuc Basin. Asoltani L. (2008) mentions this association in Călimani Mountains (Suceava County).

In Mureș County, previous studies (Oroian, 1998; Sămărghițan, 2005) record this association in the valleys of Mureș and Gurghiu rivers and on their tributaries. The coenoses with Scirpus sylvaticus are widespread in the study area. The places for the conducted 24 phytosociological surveys were chosen to cover all the study area (Fig. 1.). In the research area these communities are fragmentarily distributed, on flat land, isolated and are not used as pastures or hayfields. The studied coenoses have a low conservative value and low fodder resource being grazed by animals only at an early stage. However, they are important as ecotones that provide shelter and feeding places for many invertebrates and small mammals, so these habitats must be protected.

\section{Materials and Methods}

In order to analyze the plant communities, vegetation was sampled and phytosociological surveys were elaborated using the standard Central European method (Braun-Blanquet, 1964, Cristea et al., 2004). The data have been gathered during 2015-2019 in 24 vegetation surveys (phytocoenologic relevées). For each survey the species composition was noted. In order to assess the dominance of species in the plant communities the Braun-Blanquet scale was used. The life forms, geoelements, and ecological indicators, as well as the name of the species were based on Sârbu et al. (2013). The affiliation to higher syntaxa was made according to Coldea (2012) and Mucina et al. (2016). In order to describe the Natura 2000 habitat type two scientific works were used: Habitats in Romania (Doniţă et al., 2005), and A handbook for interpreting NATURA 2000 habitats in Romania (Gafta and Mountford, 2008). The classification of threatened species 
in the study area is based on IUCN Red list (Biltz et al., 2011) and National Red List (Olteanu et al. 1994).

\section{Results and discussions}

In the studied area 24 phytosociological surveys were conducted, each on $100 \mathrm{~m}^{2}$ surface (Table 1.). These studies show a high species diversity (98 species were identified). The phytosociological relevées were carried out on alluvial gleyic soils with moderately acidic $\mathrm{pH}$ from the hydrographic basins of the following rivers: Mureș, Gurghiu, Niraj and Târnava Mică. The land here is characterized by the stagnant water present almost all the year and the soil well soaked with water. The syntaxonomic scheme of vegetation is:

Cls. Molinio-Arrhenatheretea R. Tx.1937

Ord. Molinietalia caeruleae W.Koch 1926

All. Calthion palustris Tx. 1937

Ass. Scirpetum sylvatici Ralski 1931
The surveys were taken on the mountain belt with altitudes between 504 and $1310 \mathrm{~m}$ above sea level (asl). The climate records an average annual temperature between $7^{\circ} \mathrm{C}$ and $5^{\circ} \mathrm{C}$ and rainfalls between $650-1056 \mathrm{~mm} /$ year. The soils are alluvial, and rich in nutrients. The phytocoenoses have a good coverage $(97-100 \%)$; the structure is stratified, the higher species form the upper level, which exceeds $1 \mathrm{~m}$ in height. In the floristic composition of the association, 98 taxa were identified. Along with the edifying and characteristic species Scirpus sylvaticus (Fig. 2.), numerous species belonging to the coenotaxons that subordinate the association have been identified. The species composition of this association in the study area is similar to those of the rest of Europe (BalátováTulácková 1987, Hájek et al., 2005, Hájková and Hájek, 2007, Malovcová-Staníková, 2009.

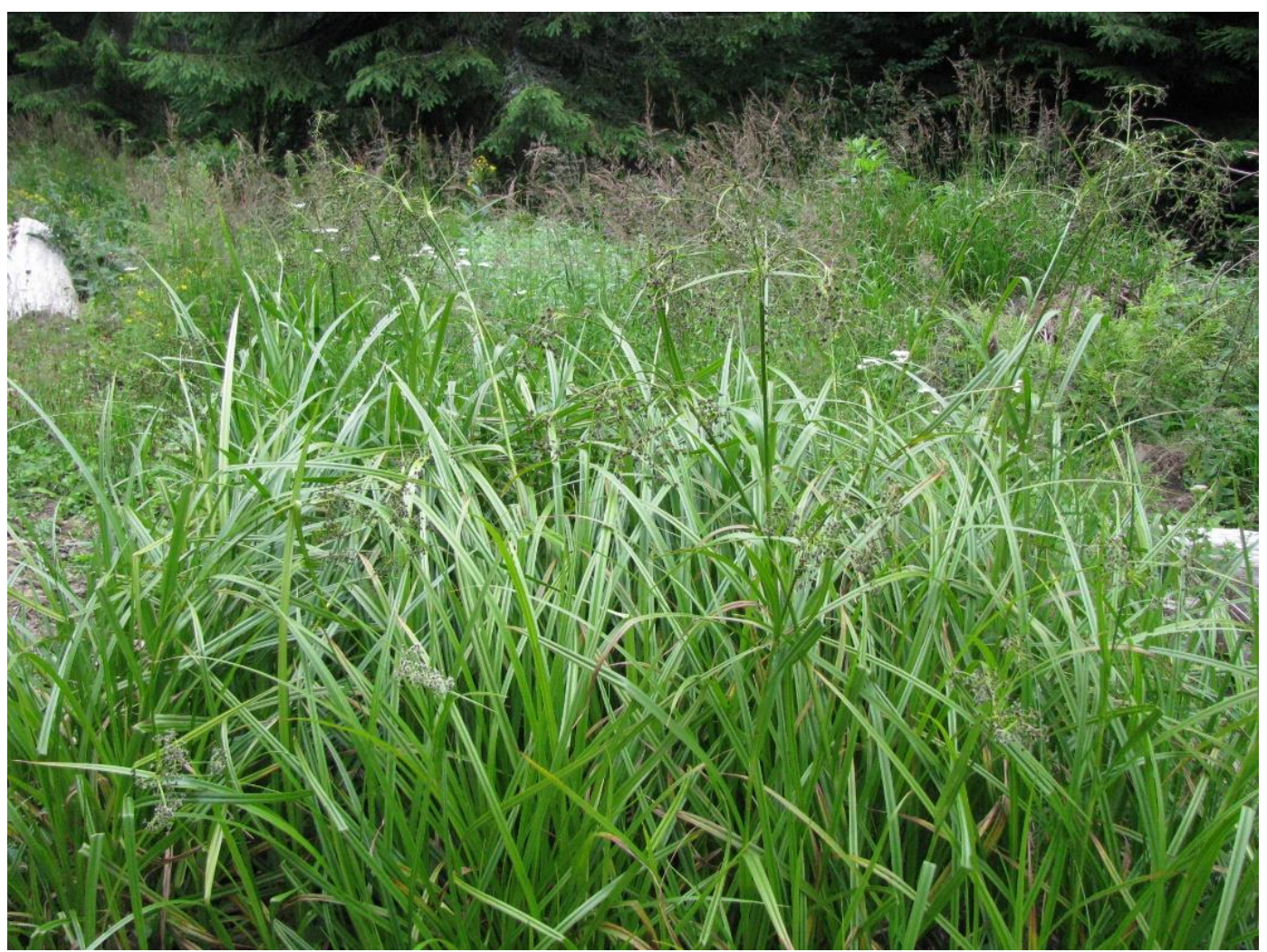

Fig. 2. Scirpetum sylvatici association on Mureș Gorge (photo Silvia Oroian) 
Considering the affiliation to various coenotic groups a dominance of the species belonging to higher syntax can be noted. Thus, some species are characteristic to Calthion alliance, such as: Caltha palustris, Chaerophyllum hirsutum, Crepis paludosa, Juncus articulatus, Myosotis scorpioides, Trifolium hybridum etc. Species with high frequency were identified from the Filipendulion alliance (Cirsium oleraceum, Epilobium parviflorum, E. hirsutum, Filipendula ulmaria, Geranium palustre, Lysimachia vulgaris, Lythrum salicaria, Mentha longifolia, and Valeriana officinalis) and the Molinietalia and Molinion alliance (Cirsium erisithales, Cirsium palustre, Dactylorhiza majalis, Galium uliginosum, Juncus effusus, Lychnis flos-cuculi, Lycopus europaeus etc.). Beside the characteristic species of Molinio-Arrhenatheretea class, in the studied communities the following taxa were present: Achillea millefolium, Agrostis capillaris, Alopecurus pratensis, Holcus lanatus, Potentilla reptans, Prunella vulgaris, Stellaria graminea etc. In the floristic composition of the association some rare and threatened plants were identified such as Angelica archangelica (LC) and Dactylorhiza majalis (LC). Their presences give a higher conservative value for the habitat.

In the coenoses with higher anthropic pressure the presence of Erigeron annuus ssp. annuиs, an alien invasive species was noticed.

For the association the analysis of geoelements and bioforms were made. The Eurasian element was dominant (51.55\%), followed by the Circumboreal which was well represented in the studied communities (20.62\%). The European elements were in a proportion of $12.97 \%$. This distribution shows the Central-European origin of Calthion vegetation with the corresponding habitat conditions (climate, relief). There is a distinct regional peculiarity because of the presence of
Alpine-Carpathian, Carpathian and CarpathianBalkan elements (4.12\%) (Fig. 3.).

According to the analysis of bioforms (Fig. 4.), the hemicryptophytes prevail (75.52\%), followed by geophytes $(10.20 \%)$ and helophytes $(4.08 \%)$. The chamaephytes represent $3.06 \%$ of the bioforms while the phanaerophytes $2.01 \%$, due to closeness with the forest belt. The percentage of therophytes was comparatively high $(5.10 \%)$, which is not typical for this kind of vegetation.

The stationary conditions in which this association develops favor a large number of light-loving species that grow generally in well-lit places, but also occurring in partial shade (L $\mathrm{L}_{7}-48.45 \%$ ), alongside with some lightloving species $\left(\mathrm{L}_{8}-21.65 \%\right)$. The thermal regime is favorable for the development of the mesothermophilous species (21.65\%) and euriterms (55.67\%). The Ellenberg indices were used to reveal the necessary moist conditions for the species within the association. Thus meso-hygrophilic species with preference for moderately wet soils $\left(\mathrm{U}_{6}=20.62 \%\right)$ and those which prefer wetter soils $\left(\mathrm{U}_{7}=17.53 \%, \mathrm{U}_{8}=15.46 \%\right)$ are dominant. In terms of preference to soil reaction most species of this association are eurionic $(56.7 \%)$ or indicator of moderate acidity, occurring rarely in strongly acidic or in neutral to alkaline soil conditions (19.59\%). They occur in nutrient-poor sites more frequently than in sites with moderate nutrient supply and exceptionally in sites with rich nutrients $\left(\mathrm{N}_{3}-\right.$ $15.46 \%)$ (Fig. 5.).

The phytocoenoses analyzed in this study belong to Natura 2000 Habitat 6430 Hydrophilous tall-herb fringe communities of plains in the montane to alpine levels. This habitat is wide spread in the area; the herb layer is usually tall and the cover is highly variable depending on the mechanical action of water and level fluctuations. 


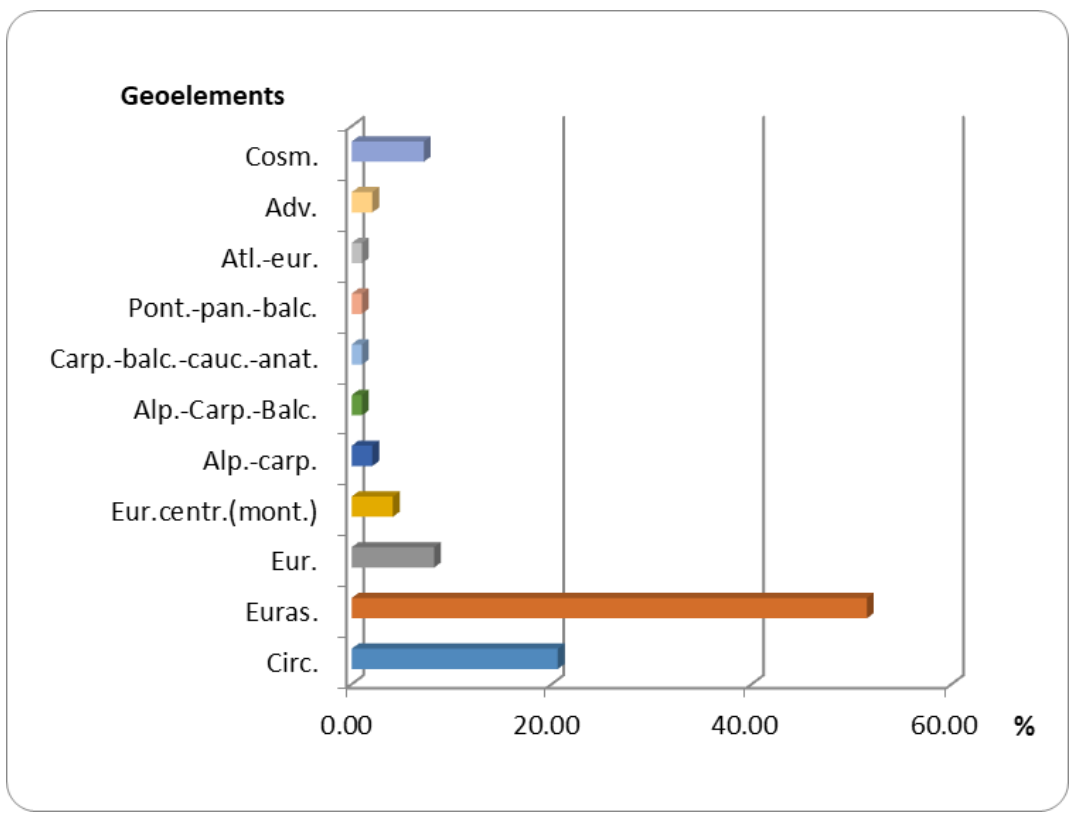

Fig. 3. Geoelements of Scirpetum sylvatici association

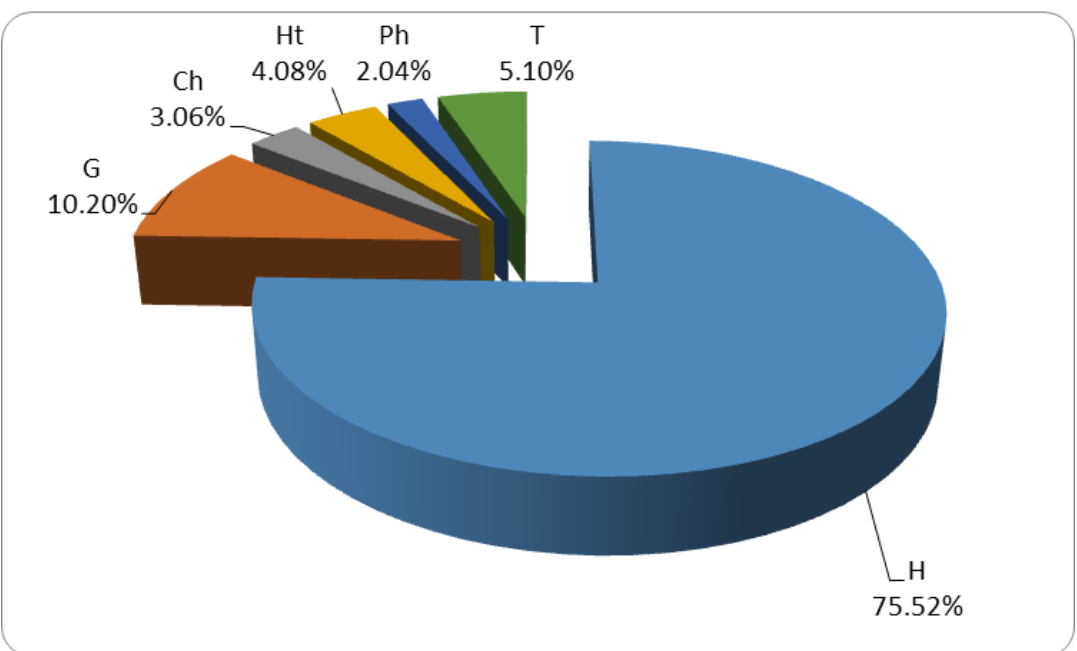

Fig. 4. Bioforms spectrum of Scirpetum sylvatici association

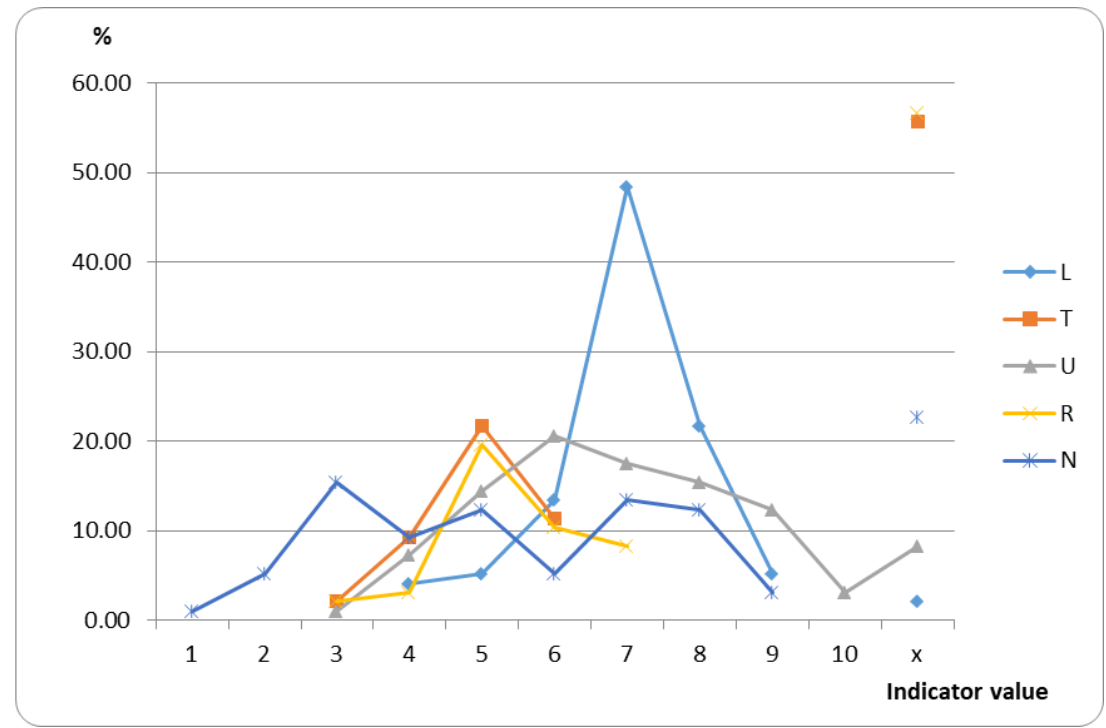

Fig. 5. Ecological indices of Scirpetum sylvatici association 
The anthropogenic threats are numerous, generally affecting the biodiversity. The main pressures/threats estimated from the field study refer to forest management and use. In the Călimani-Gurghiului mountains was noticed the transport of the exploited wood with trucks or heavy equipment. These affect the banks of the Mureş tributaries, where these phytocenoses occur, leading to the damages on large areas of the habitat. It also causes the settlement of the wet soil, favoring the erosion processes that in time create free spaces on the ground for the installation of weeds and invasive alien species. Also moist soil settlements might affect the underground part (rhizomes) of some plants that ensure their perennial and vegetative reproduction, thus leading in time to the reduction of the population. Therefore, it is recommended to supervise the activity of wood exploitation by

\section{Conclusions}

In the study area, the hygrophilous plant communities dominated by Scirpus sylvaticus were included in the association Scirpetum sylvatici Ralski 1931. These stands belong to Natura 2000 Habitat 6430 Hydrophilous tallherb fringe communities of plains in the montane to alpine levels. The 24 phytosociological surveys highlight the biodiversity of these communities that comprise 98 plant species. The floristic composition of the association is similar with those described in Europe. The diagnostic and characteristic species of association are present and have a good coverage up to $100 \%$. In these phytocoenoses some threatened species were identified such as Angelica archangelica (LC) and Dactylorhiza majalis (LC). In the study area these phytocoenoses are mostly in a good and very good state of conservation and they can be considered frequent in the area. the companies involved. Drought and reduced rainfall in recent years have led to the reduction of phytocenoses dominated by Scirpus sylvaticus.

Regarding the conservation status, it can be mentioned that the habitat is in very good (45.84\% of the surveys carried out) or good conservation condition ( $45.84 \%$ of the surveys carried out) and only in $8.34 \%$ of the surveys, the conservation status of the habitat is satisfactory. As such, the following short term impact of risk factors can be mentioned: the restriction of characteristic plant communities in favor of ruderal ones, and changes in the structure and composition of the vegetation due to the proliferation of invasive species. Therefore, permanent monitoring is required to obtain information on the evolution trends of the habitat in order to preserve the habitat conservation status.

\section{Conflict of Interest}

The authors declare that the research was conducted in the absence of any commercial or financial relationships that could be construed as a potential conflict of interest.

\section{References}

1. Asoltani L. (2008) Contributions to the study of paludal vegetation from the Neagra Şarului river's basin (Suceava county), Analele ştiinţifice ale Universităţii “Al. I. Cuza" Iaşi, Tomul LIV, fasc. 1, s. II a. Biologie vegetală, Iași

2. Balátová-Tulácková E, (1987) Beitrag zur Kenntnis der Feuchtwiesen des Gebirges Hostynské vrchy. Tuexenia 7:199-213 http://publikationen.ub.unifrankfurt.de/files/38065/balatovatulackova_ 1987_hostynskevrchy.pdf 
3. Bilz M, Kell SP, Maxted N, Lansdown RV (2011) European Red List of Vascular Plants. Luxembourg: Publications Office of the European Union

4. Braun-Blanquet J (1964) Plant sociology. The study of plant communities. Ed.3. Wien-New York: Springer Publishing

5. Coldea Gh (ed.) (2012) Les association végétales de Roumanie, Tome 2 Les associations anthropogènes, Edit. Presa Universitară Clujeană, Cluj Napoca

6. Cristea V, Gafta D, Pedrotti F (2004) Fitosociologie. Edit. Presa Universitară Clujeană, Cluj-Napoca

7. Doniţă N, Popescu A, Paucă-Comănescu M, Mihăilescu S, Biriş I.A (2005) Habitatele din România, Ed. Tehnică Silvică, Bucureşti

8. Gafta D, Mountford O (coord.) (2008) Manual de interpretare a habitatelor Natura 2000 din România, Ed. Risoprint, ClujNapoca

9. Gergely I, Raţiu F (1973) Vegetaţia mlaştinilor eutrofe din bazinul superior al Ciucului, Contrib. Bot. Cluj:143-165.

10. Hájek M, Tzonev R T, Hájková P, Ganeva AS, Apostolova I I (2005) Plant communities of subalpine mires and springs in the Vitosha Mt. Phytologia Balcanica, 11:193-205.

11. Hájková P, Hájek M (2007): TDF08 Scirpetum sylvatici Ralski 1931. In: Chytrý M. (ed.), Vegetace České republiky. 1. Travinná a keříčková vegetace [Vegetation of the Czech Republic. 1. Grassland and Heathland Vegetation]. Academia, Praha, pp. 264-266.

12. Kulik M, Baryła R, Warda M, Stamirowska-Krzaczek E. (2016) Vegetation changes of the MolinioArrhenatheretea class in the Bystra valley, eastern Poland. Acta Agrobot, 69(4):1689. http://dx.doi.org/10.5586/ aa.1689.
13. Malovcová-Staníková $\quad$ M

(2009)

Communities Scirpetum sylvatici and Epilobio palustri-Juncetum effusi in the Borská nížina Lowland, Bull. Slov. Bot. Spoločn., Bratislava, 31(2):35-39.

14. Mucina L, Bültmann $H$, Dierßen $K$, Theurillat J P, Raus T, Čarni A, Šumberová $\mathrm{K}$, Willner W, Dengler J, García RG, Chytrý M, Hájek M, Di Pietro R, Iakushenko D, Jens Pallas J, Daniëls FJA, Bergmeier E, Santos Guerra A, Ermakov N, Valachovič M, Joop H.J. Schaminée JHJ, Lysenko T, Didukh YP, Pignatti S, Rodwell JS, Capelo J, Weber HE, Solomeshch A, Dimopoulos P, Aguiar C, Hennekens SM, Tichý L (2016) Vegetation of Europe: hierarchical floristic classification system of vascular plant, bryophyte, lichen and algal communities. Applied Vegetation Science 19, Suppl. 1:3264.

15. Oltean M, Negrean G, Popescu A, Roman N, Dihoru G, Sanda V, Mihăilescu S (1994) Listă roşie a plantelor superioare din România, Studii, sinteze, documentaţii de ecologie, 1, Acad.Română, Instit. de Biologie, Bucureşti

16. Oroian S (1998) Flora şi Vegetaţia Defileului Mureşului între Topliţa şi Deda, Casa de Ed. Mureş

17. Pascal P, Mititelu D (1971) Contribuţie la studiul vegetaţiei din bazinul Bistriţei Aurii (Jud. Suceava), Comunic Şti. Inst. Pedagog., Iaşi, pp. 331-363.

18. Sămărghiţan M (2005) Flora şi vegetaţia Văii Gurghiului, Ed. University Press, Târgu-Mureş

19. Sârbu I, Ştefan N, Oprea A, (2013) Plante vasculare din România, determinator ilustrat de teren. Ed. "Victor B. Victor", Bucureşti 


\begin{tabular}{|c|c|c|c|c|c|c|c|c|c|c|c|c|c|c|c|c|c|c|c|c|c|}
\hline & & & & $\simeq$ & & $>$ & & $\geq$ & $=$ & - & $=$ & - & $>$ & $\equiv$ & & $=$ & $\Xi$ & $>$ & - & $\Xi$ & 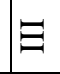 \\
\hline & $\mathbb{N}$ & & $69 L$ & & & $n$ & & + & + & , & ' & , & + & + & & ' & , & + & + & + & + \\
\hline & $\ddot{\sim}$ & & tos & & & $n$ & & ' & 1 & ' & + & + & + & ' & & ' & ' & + & 1 & + & , \\
\hline & สี & & IEO I & & & $n$ & & + & + & + & , & ' & + & ' & & ' & + & + & ' & ' & + \\
\hline$\underset{\Xi}{\Xi}$ & $\bar{\sim}$ & & I I I I & & & in & & ' & + & ' & + & + & + & + & & + & ' & + & ' & ' & + \\
\hline 童 & సิ & & I $\angle 6$ & & & $n$ & & + & + & ' & ' & ' & + & + & & ' & + & + & + & + & , \\
\hline 氕 & 2 & & I66 & & & in & & + & + & ' & 1 & ' & ' & ' & & 1 & + & 1 & ' & & ' \\
\hline$\stackrel{\mathrm{z}}{\mathrm{z}}$ & $\stackrel{\infty}{\infty}$ & & ऽ6I I & & & in & & + & 1 & 1 & ' & 1 & + & ' & & 1 & + & + & 1 & 1 & 1 \\
\hline छ్ & 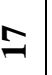 & & $6 \mathcal{E L I}$ & & & $n$ & & + & . & ' & + & ' & + & ' & & , & + & + & , & , & + \\
\hline 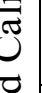 & 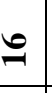 & & I66 & & & in & & + & 1 & 1 & 1 & 1 & + & + & & 1 & + & 1 & , & + & . \\
\hline $\begin{array}{l}\bar{\Xi} \\
\equiv\end{array}$ & $\stackrel{2}{2}$ & & $\varepsilon 90 \mathrm{I}$ & & & in & & + & + & ' & ' & ' & + & + & & ' & + & + & , & + & + \\
\hline$\vec{E}$ & \pm & & OIEI & & & in & & + & 1 & , & , & ' & + & + & & ' & + & + & , & + & , \\
\hline 5 & 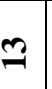 & & $\varepsilon \neq 6$ & & & in & & ' & ' & ' & ' & ' & + & ' & & ' & & + & , & + & + \\
\hline & $\simeq$ & & t86 & & & in & & + & , & , & 1 & , & + & + & & + & + & + & , & + & , \\
\hline ك & $=$ & & I6I I & & & in & & , & , & , & , & , & + & + & & + & , & + & , & ' & , \\
\hline ¿ & $\underline{\underline{\theta}}$ & & EZI I & & & in & & + & , & 1 & , & , & + & + & & , & + & + & , & , & , \\
\hline $\bar{n}$ & $a$ & & 6I0I & & & in & & + & . & + & ' & ' & + & ' & & ' & ' & + & + & + & + \\
\hline & $\infty$ & & $t \mathrm{C} \mathrm{I}$ & & & in & & + & , & + & + & , & + & + & & , & , & + & , & + & , \\
\hline$\frac{y}{c}$ & $r$ & & 986 & & & $n$ & & + & I & ' & ' & ' & + & ' & & ' & + & + & + & ' & , \\
\hline$\Xi$ & 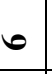 & & OEZI & & & in & & + & ' & 1 & + & ' & + & + & & + & ' & + & ' & ' & ' \\
\hline $\begin{array}{l}\overrightarrow{2} \\
\equiv\end{array}$ & ת & & $L \varepsilon 6$ & & & in & & , & ' & ' & 1 & , & + & , & & . & , & + & , & & + \\
\hline $\begin{array}{l}5 \\
\tilde{\Xi} \\
\tilde{\Sigma}\end{array}$ & + & & 90 I I & & & $n$ & & + & 1 & 1 & . & , & + & ' & & ' & + & + & , & ' & . \\
\hline s. & $m$ & & 228 & & & in & & 1 & ' & 1 & ' & ' & + & , & & ' & 1 & ' & 1 & 1 & + \\
\hline$\frac{0}{2}$ & $N$ & & $87 t L$ & & & $n$ & & 1 & + & + & ' & ' & + & ' & & + & ' & ' & ' & ' & + \\
\hline & - & & $8 t L$ & & & $n$ & & , & + & , & , & . & + & + & & . & , & + & , & + & , \\
\hline & 总 & 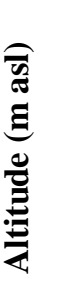 & & & 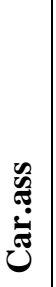 & 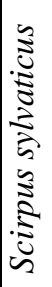 & שֶ & 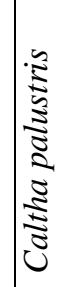 & 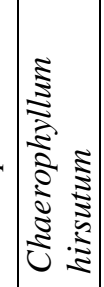 & 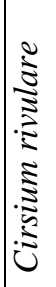 & 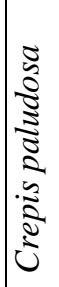 & 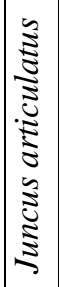 & 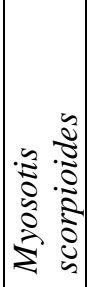 & 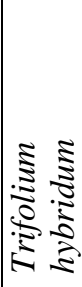 & 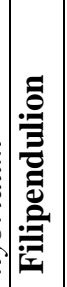 & 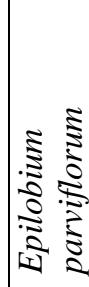 & 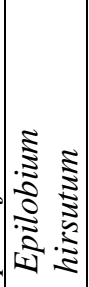 & 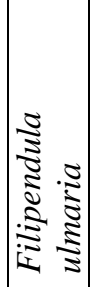 & 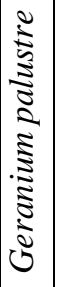 & 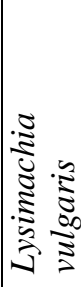 & 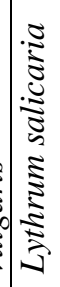 \\
\hline
\end{tabular}




\begin{tabular}{|c|c|c|c|c|c|c|c|c|c|c|c|c|c|c|c|c|c|c|c|c|c|c|}
\hline$\geq$ & $=$ & & - & - & $z$ & $=$ & $\equiv$ & $\Xi$ & $\geq$ & $\Xi$ & $=$ & - & $=$ & & - & - & - & $=$ & $=$ & - & - & $=$ \\
\hline+ & . & & + & ' & + & + & + & 1 & + & + & ' & + & ' & & , & ' & 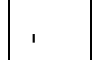 & I & + & I & . & + \\
\hline 1 & + & & 1 & ' & 1 & ' & + & + & ' & 1 & 1 & + & 1 & & 1 & ' & + & I & + & I & ' & . \\
\hline+ & I & & ' & I & + & + & + & ' & + & + & + & ' & + & & ' & ' & , & I & + & + & ' & . \\
\hline+ & ' & & ' & + & + & ' & 1 & + & + & + & + & ' & 1 & & 1 & ' & ' & + & ' & 1 & ' & I \\
\hline+ & ' & & ' & ' & + & ' & , & + & I & , & ' & , & ' & & I & ' & 1 & + & + & , & , & + \\
\hline+ & ' & & ' & ' & + & ' & ' & ' & + & ' & ' & ' & ' & & + & ' & ' & I & + & I & ' & . \\
\hline+ & ' & & ' & ' & 1 & ' & I & 1 & + & ' & 1 & ' & ' & & ' & . & 1 & + & + & ' & , & . \\
\hline+ & , & & ' & ' & ' & ' & I & , & + & 1 & , & ' & ' & & ' & ' & ' & + & + & ' & ' & + \\
\hline+ & ' & & ' & I & + & + & + & + & + & + & ' & + & ' & & I & + & , & + & , & I & I & + \\
\hline+ & + & & I & I & + & + & + & + & I & + & + & I & I & & I & , & I & I & ' & , & , & + \\
\hline+ & I & & + & + & + & , & + & + & + & + & . & I & I & & I & 1 & ' & + & ' & ' & ' & + \\
\hline+ & ' & & ' & I & + & ' & + & ' & + & ' & + & 1 & 1 & & ' & I & , & 1 & ' & 1 & ' & . \\
\hline+ & ' & & + & 1 & + & ' & + & + & + & + & ' & 1 & 1 & & ' & 1 & 1 & + & ' & ' & ' & + \\
\hline 1 & + & & ' & ' & + & ' & ' & . & + & ' & 1 & 1 & ' & & ' & + & ' & + & + & + & ' & , \\
\hline ' & ' & & ' & ' & ' & + & I & ' & I & I & ' & ' & ' & & ' & ' & ' & I & ' & ' & ' & , \\
\hline+ & + & & ' & I & + & ' & + & . & + & + & 1 & 1 & 1 & & ' & 1 & 1 & ' & ' & ' & + & 1 \\
\hline+ & + & & ' & I & + & , & + & , & + & + & I & ' & ' & & + & ' & ' & I & ' & ' & + & I \\
\hline+ & , & & ' & + & 1 & + & + & ' & + & + & + & ' & + & & + & ' & + & I & ' & ' & ' & . \\
\hline ' & ' & & ' & + & 1 & ' & + & + & + & + & + & ' & + & & ' & ' & + & I & ' & ' & I & I \\
\hline I & . & & + & 1 & + & . & ' & + & . & 1 & ' & ' & + & & I & . & , & ' & ' & I & ' & . \\
\hline ' & + & & I & I & + & ' & ' & + & ' & + & ' & ' & , & & I & ' & ' & I & ' & ' & I & 1 \\
\hline+ & I & & ' & I & + & ' & + & + & + & ' & + & + & ' & & ' & 1 & I & ' & ' & ' & I & 1 \\
\hline+ & ' & & ' & 1 & + & . & ' & ' & + & . & + & ' & + & & ' & ' & ' & ' & ' & ' & ' & 1 \\
\hline+ & + & & ' & ' & 1 & ' & + & + & ' & + & + & ' & ' & & . & ' & I & ' & + & ' & + & 1 \\
\hline 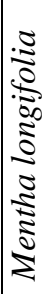 & 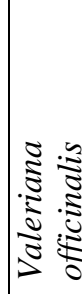 & 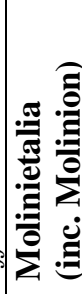 & 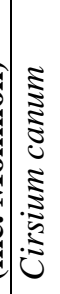 & 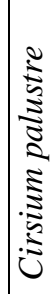 & 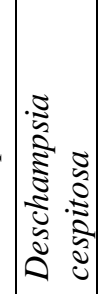 & 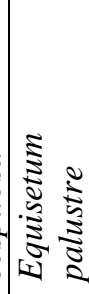 & 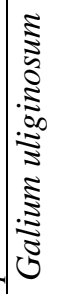 & 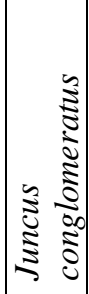 & 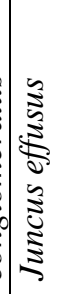 & 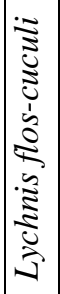 & 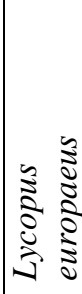 & 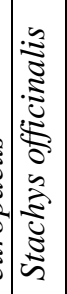 & 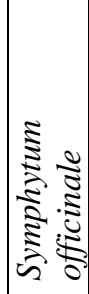 & 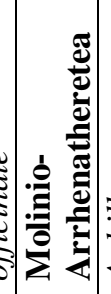 & 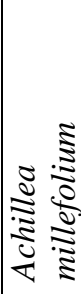 & 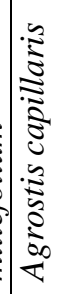 & 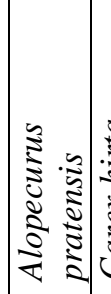 & 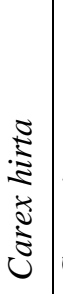 & 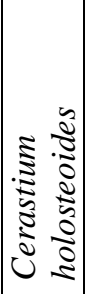 & 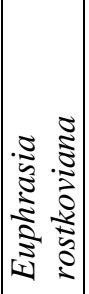 & 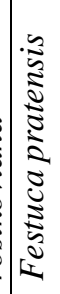 & 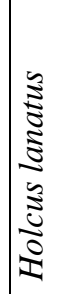 \\
\hline
\end{tabular}




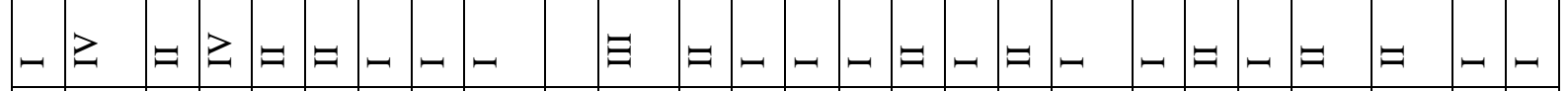

\begin{tabular}{|c|c|c|c|c|c|c|c|c|c|c|c|c|c|c|c|c|c|c|c|c|c|c|c|}
\hline+ & + & + & + & & ' & + & & + & I & 1 & , & ' & & , & 1 & 1 & I & , & , & 1 & 1 & 1 & \\
\hline ' & I & + & + & + & , & + & I & , & + & I & , & I & + & , & + & , & + & , & I & I & I & ' & ' \\
\hline ' & ' & + & + & ' & ' & ' & ' & + & ' & ' & ' & ' & + & ' & ' & + & ' & ' & ' & ' & ' & ' & I \\
\hline ' & ' & + & + & + & ' & ' & & + & ' & ' & ' & I & ' & ' & + & ' & ' & ' & ' & + & ' & ' & I \\
\hline ' & I & + & + & ' & I & I & ' & + & I & ' & I & I & ' & + & ' & ' & ' & , & ' & + & ' & ' & ' \\
\hline+ & 1 & & + & I & ' & ' & &, & , & ' & + & ' & , & ' & + & 1 & ' & + & ' & + & + & ' & + \\
\hline
\end{tabular}

\begin{tabular}{|lllllllllllllllllllllllllllllllllllllll}
1 & + & + & + & + & 1 &, &, &, & & 1 & + & 1 & 1 & + & 1 & 1 & + & 1 & + & + & 1 & 1 & + & 1 & 1 \\
\hline
\end{tabular}

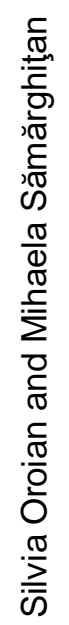

\begin{tabular}{|c|c|c|}
\hline+ & ' & r \\
\hline
\end{tabular}

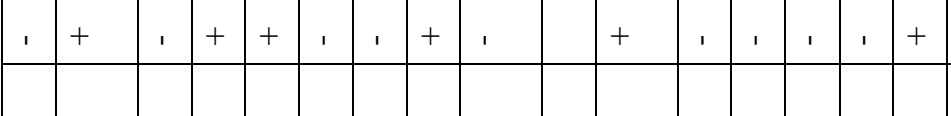

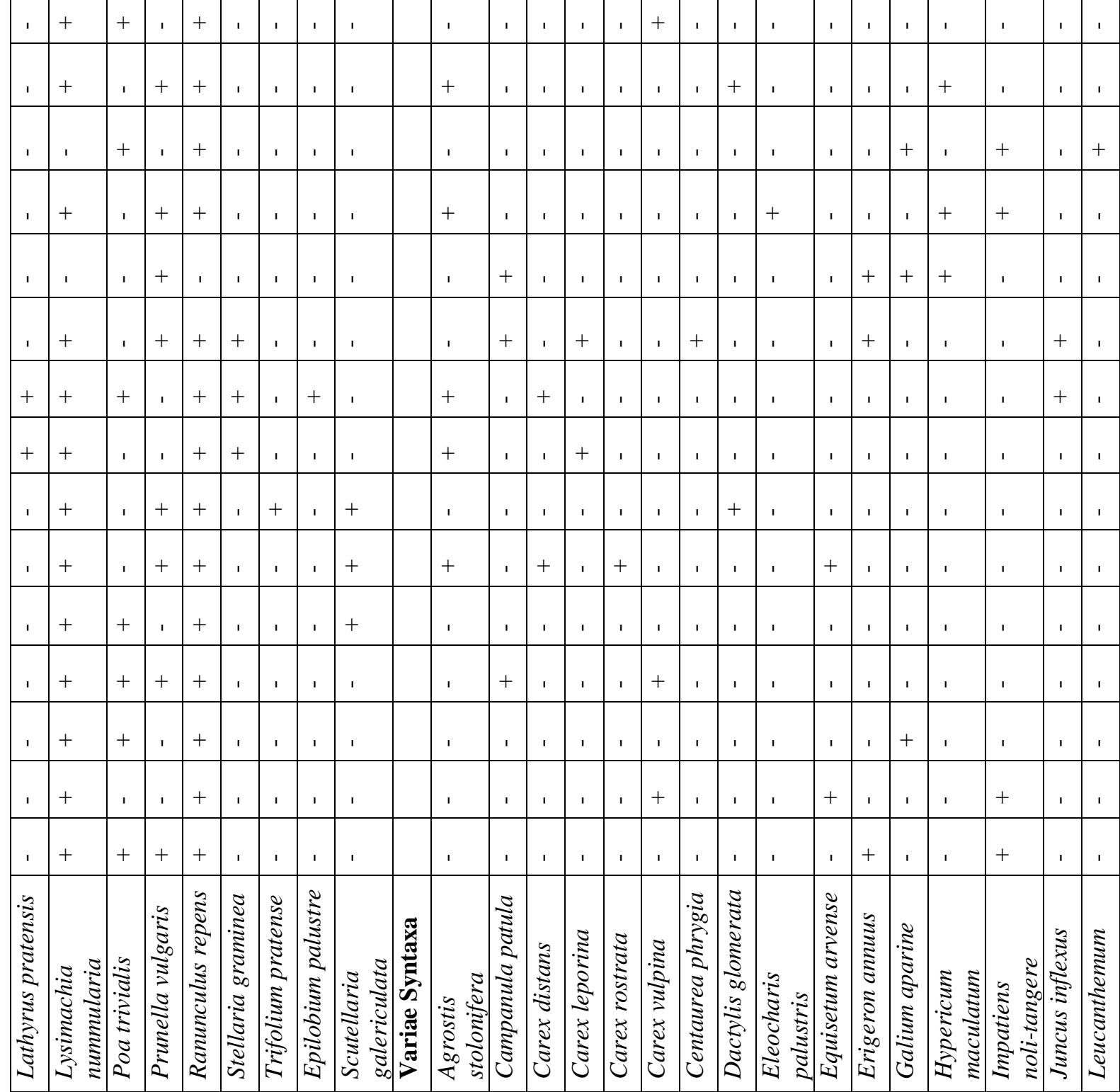




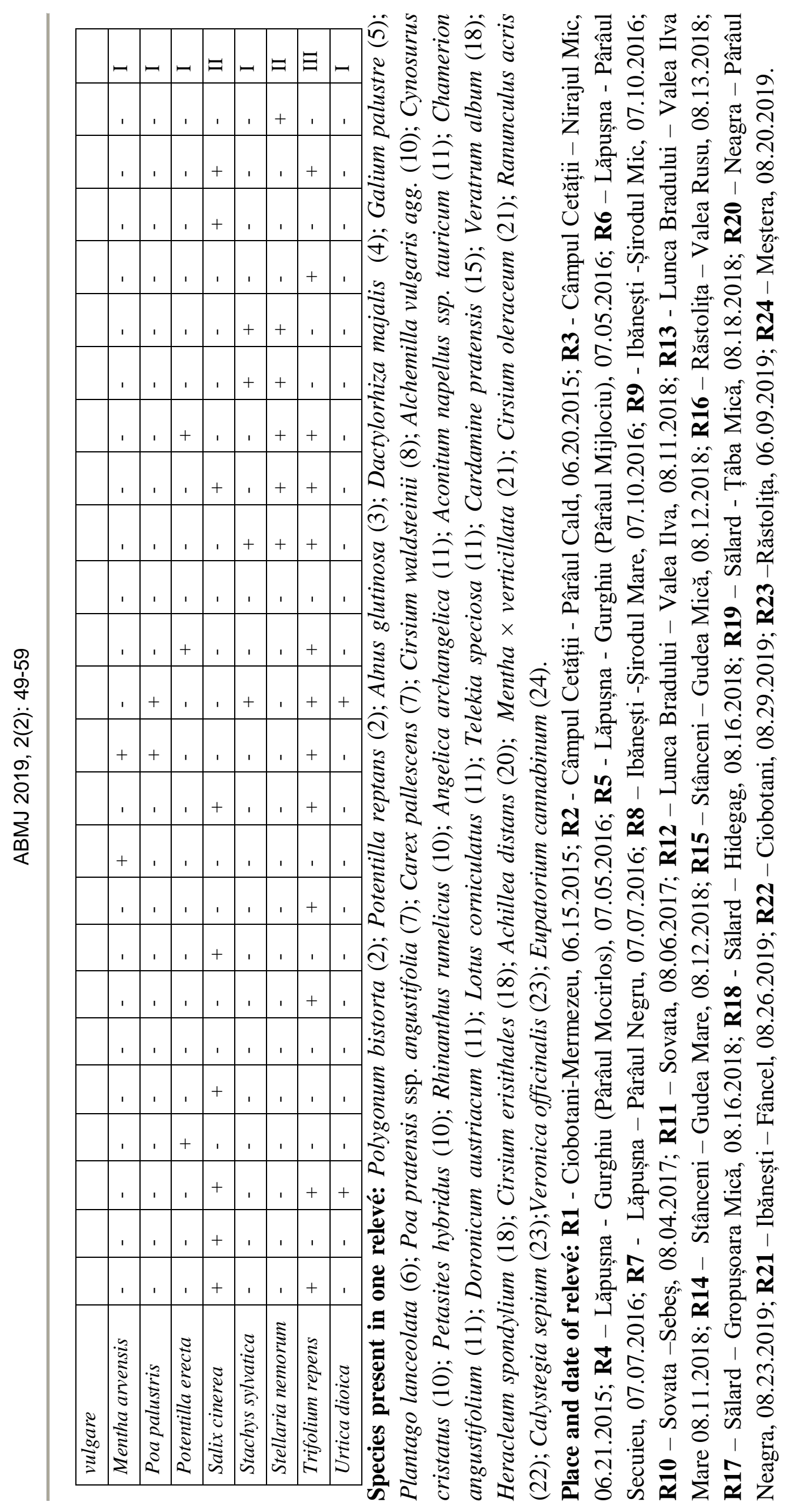

